\title{
SELF-FASHIONING IN RENAISSANCE DUBROVNIK: MARIN DRŽIĆ VIDRA (1508-1567)
}

\section{Irena Arsić ${ }^{1}$}

Faculty of Philosophy, University in Niš, Republic of Serbia
Review paper

DOI:10.21554/hrr.091709

Received: 18.05 .2017

Accepted: 10.07.2017

\begin{abstract}
Modern interpretation methods of the most important works of European Renaissance provide new opportunities in the interpretation of comedies of Dubrovnik writer Marin Držić. This especially applies to the theory of the new historicism, whose most important representative Stephen Greenblatt in his classic work Renaissance self-fashioning, provides an opportunity to examine Držić and his work according to this theory that deals withthe identity of the Renaissance creators, which was also the goal of this work. In this way new and more detailed analysis of Držić pastoral, farce and Plautuscomedy was opened, which will prove againthe classical quality and timeless value of the dramatic work of the greatest renaissance writer in our region.
\end{abstract}

Key words: Dubrovnik, Renaissance, Marin Držić, identity, new historicism, subversive literature, self-fashioning

\section{INTRODUCTION}

Literature of Humanism, Renaissance and Baroque, created on the territory of the old Dubrovnik Republic, has reached European levels through its achievements. In these centuries, Dubrovnik creators which in the cultural, artistic and literary sense belonged to stated periods, lived, educated, and then created their works in the European environment and in that way became the part of the European literature elite. In this sense, their work today can be considered according to the criteria of the European literary tradition. This applies particularly to the most prominent representatives of Dubrovnik's renaissance and baroque, that is to Marin Držić and Gundulić Ivan.

Although the work of the greatest Dubrovnik Renaissance playwright Marin Držić (c. 1508-1567) was regularly stated in overviews of old Dubrovnik biographers and chroniclers, he did not hold the place that his counterpart in the Baroque period, Ivan Gundulić, had for centuries. In that way, Držić was almost forgotten for centuries, and it was only in the nineteenth century the one of his comedies was published in the Dubrovnik journal Dubrovnik magazine (Držić, 1870), while the revival of his work awaited only the twentieth century. Extreme interestthat followed, with numerous editions of all his dramatic works, as well as their set on the scene, was especially actualized after Držić's conspiratorial letters were found (Dayre, 1930), which enabled a new interpretation of his work. These interpretations of Držić's works ranged up to noting social unrest and resistance to aristocratic government. Modern interpreting ways of the most important works of the European Renaissance also provide opportunities for reviewing Marin Držić's comedy work in this regard. This especially applies to the theories of the new historicism, whose most important representative, Stephen Greenblatt, in his classic work Renaissance Self-Fashioning (Greenblatt, 1980) provided an opportunity to examine Držić and his work according to this theory that deals with the identity of the Renaissance creators.

\footnotetext{
Correspondence to:

Irena Arsic, PhD, Faculty of Philosophy, University in Nis, Republic of Serbia

Phone: +381648013397

e-mail: irena.arsic@filfak.ni.ac.rs
} 
Namely, the identity, which represents the sense of personal order, the specific way of addressing the world, is expressed through a collection of testimonies of individuals about themselves and the specific type of social and cultural activities (Brubaker \& Cooper, 2000). Within literary works, a writer has many opportunities for this kind of expression, and he does that through its characters. Namely, he loads his identity and forms a hero as his literary double. During the Renaissance, the relationship between intellectuals and the powerful starts its redefining. The old social forms are disbanded, and the new ones haven't beenformed yet. In addition, it is a time of layman intellectuals who are free from the authority of the church, at least temporarily, and who enterinto a special relationship with those who represent power. In doing so, they adapt with self -fashioning consciousness to the points of power, initially concentrated in the government system, but, again, in the church, and others who represent power - family, first of all.

Self-fashioning is a process, self-conscious, willing design of one's public figure, from dressing and behaviour to opinion, in accordance with socially acceptable standards of a certain society. Individuals, especially sensitive ones, such as creators, are aware of the consequences of this process, the responsibilities and of the dangers that this process bears.

Dubrovnik Renaissance was not excluded from this process. Its most prominent representative, playwright Marin Držić, his work and his biography are an illustrative example of self-fashioning.

The start of Marin Držić's literary work testifies to a very good position that poet established through his love Petrarchan verses and pastoral scenes. Cheerful spirit, literary knowledge and theatrical experience gained first in Siena, and later in other cities of Italy, allowed Držić to present himself in the pastoral prologue Tirena (Držić 1963, pp. 27-28) in a special place, in an idyllic setting, near water, surrounded by fairies ( "with the fairies by the water"), with the laurel on his head ( "made worthy of laurel wreath"), and ready to celebrate its republic ("to celebrate this country to heaven"). He considers himself the successor of the first Dubrovnik Petrarchists, his uncle Džore Držić and poet Šiško Menčetić. However, the idyll does not last long. Very soon the authorship of this magnificent pastoral was doubted. This makes the writer angryand he decides to protect his previous work from accusations of plagiarism by a special mean for that time. Therefore he prints them in Venice in 1551 and dedicates work to Dubrovnik patri- cian Pucić Maro, whom he begs to protect his work from wicked tongue and defamation with his virtues and good voice (Držić, 1963, p. 21).

This act is also supported by prominent MavroVetranović, which has been otherwise incorrectly referred to as the author of Tirena, through his song A poem of support for Marin Držić, which explicitly states that he "... is stealing from nobody" (Vetranović, 1994, pp. 127-131), which, apparently, hasn't been enough to stop rumours and liberates the true author from suspicions.

Poet's anger and bitterness were not calmed. Already in a farce Novela od Stanca (Držić, 1963:89-111) Držić criticizes the moral of Dubrovnik citizens, which is exposed by Miroslav Pantić (Pantić, 1984, pp. 4-16), identifying the alleged fairies with unfortunate ladies ofthe night in Dubrovnik then. They couldn't rejuvenate the elderly or Stanac, Držić's reluctant hero, but they were able to transmit the deadly sexually disease thathad, the writer skilfully found, initialsymptoms similar to rejuvenation. To this hilarious situation laughed uproariously those who had been able to lead such a secret unworthy life.

Perhaps more important than these moral sparklets was the possibility that Držić just sensed in his farce Novela od Stanca. Engaging in an attack on the customs of society, which at the time was very dangerous and regularly sanctioned, Držić was already thinking about a certain hiding (masking), which lead to the idea of constructinghis public identity. This was first through the idea of conscious mask manipulation and then through the concrete shaping of his public identity.

The main character, a young nobleman Dživo Pešica, skilled and cheerful joke teller to an aging Stanac, has been recognized, first of all, by the audience, as an actor, since he is being addressed as "our old Radate," that is by the name of character from pastoral Tirena where this young man from Dubrovnik probably has acted (Držić, 1963, p. 96). In addition to thisrevealed identity, Držićis using the case of the same figure to indicate the possibility of construction of another identity: DživoPešica in farce, in front ofStanac, ispretending to be a successful merchantfrom Dubrovnik in order to obtain his confidence. Even that hasn'tseemed enough to Držić's playful imagination. That merchant, who describes the life of a common citizenof Dubrovnik Renaissance in completely authentic manner, has a name completely out of the real context: he calls himself an Eighth Husband and delves into the carnival-magic area. 
In this way, Držić's hero is expressed in complex identity construction: he is an actor, a family member who performs Držić's plays, Radat from Tirena, he is Dživo Pešica in Novella od Stanca, but also a successful merchant from Dubrovnik. He is also a mysterious eighth husband, who is linked to the name of Magician - Seventh Husband from Držić's plautan comedy Dundo Maroje, and probably from his lost comedy Pomet. Through these numerous possibilities of establishing identity in terms of a single person, Držić isclearly preparing to shape his own public identity. This is his introduction to the self-fashioning, which is claimed by Greenblatt as narrative fiction, project with an aim to make a part of one's own, to live one's life as a character thrust into a play, constantly renewing oneself extemporaneously and forever aware of one's one unreality (Greenblatt, 1980, p. 31).

This kind of Držić'simagination is recognized in his most successful work, in the comedy Dundo Maroje (Držić, 1963, pp. 113-293), where he is still hesitating between two ways of his own subversive activities in relation to public opinion, ruling moral norms and the government.

The first mode is shown in the prologue of the Long Nose Magician: Držić criticizes his environment, presenting it allegorically, so that the audience, which is subject to criticism, is not aware of it. This dangerous game was probably very interesting to comedian, especially since a lot of excitement came along with it: in case any of numerous representativesof aristocratic parliamentarian government which for centuries ruled Dubrovnik had recognized himselfin men "untrue" (false, evil people), and not in "true" people (true, genuine people) that would cost Držić his life.

Držić is clear that true, real, genuine people are: "looser, quiet people, wise peopleand reasonable people." And, most importantly, "the heart is not under a mask, they bear their heart in front of their eyes so everyone sees their good thoughts ..." (Držić, 1963, pp. 115118).

The second method has been widely explained, and presents Držić's reconsidering in identity shaping, where he names this process as - "akomodovanje" (adjustment). Here is self-fashioning expressed as a narrative feature - Pomet Trpeza, servant-manipulator, consciously shapes his behaviour anticipating the situation and further development. He argues that one should be very skilled and time adapting. Namely, it is not important to have money, because many who have money are depressed; it is not important to be educated, because they are usually full of worries and tend to fantasize; is not important to be a hero with a sword in a hand, because dungeons are full of these, or they are killed. It is important, Pomet says, to know how to behave in evil times, in order to enjoy good times (Držić, 1963, pp. 161-163).

At that time, Držić's impression of himself as a writer and comedian has been already changed. The one who writes comedies, Držić says, everyone use to ridicule and instead to show him gratitude, they send him away with insults and became his enemies. Thus when author sets his work on stage and acts in them, he often has to sing when he would preferably cry (Držić, 1963, pp. 161-163)

From hiding behind masks, through attempts to structure its various identities while using his dramatic heroes, the writer is fully aware of its own status as an invention. Such mental-psychological situation is followed by perpetual self-reflexiveness and perpetual self-estrangement (Greenblatt, 1980, p. 31).

In that way, from irony over the sarcasm in his dramatic works, Držić gets to the tragic tones.

First, a comedy Skup (Držić, 1963, pp. 295-367) shows a bleak picture of the Dubrovnik nobility through the character of passionate miser. The personality of Dubrovnik nobleman in this comedy is much dehumanized as compared to another Dubrovnik'smiser UncleMaroje. All the values of his life, beginning with the most intimate parent values, are subordinated tothe passion for possession, to gold as a symbol of the Dubrovnik society at that time. This indicates a more open comedian appearance and specific disclosure of his attitude towards the modern Dubrovnik and its authorities and the social and moral norms. This is the result of Držić's mental and physical condition, since the writer is aware that "all ... are caught up in receding layers of fantasy." Therefore, he "laughs oris angry to see another pride himself on a mere fiction, while he himself is no less a player, no less entrameled in fantasy" (Greenblatt, 1980, p. 27).

Finding himself in this condition, the writer is only a step from an escape from the narrative, achieving the dream of a cancellation of identity itself andan end to all improvisation (Greenblatt, 1980, p. 32). The feeling of absurdity leads to social criticism, that is, when it comes to Držić, to the attempt of the actual actions against the source of power, that is, Dubrovnik authorities. 
This is the moment when Držić's conspiratorial lettersare written (Držić, 1963, p. 369-387; Kunčević, 2007, pp. 9-46), in which he boldly asks for the intervention of the Florentine dukes of Medici for a change of government in Dubrovnik.

Dubrovnik nobility which governs the Republic, Držić called "twelve monsters, unarmed, foolish, worthless," citing unconvincing examples of their poor management of state affairs, the economy, the judiciary. His plans for the conquest of power are also naive, since he asks fromCosimo de 'Medici and his son Francesco only fifty soldiers with four captains, poorly armed (only with a sword), that he would meet in Dubrovnik, with the prior anathema (true or false) given by the Roman Pope. The aim is to dethrone the current regime, to form a parliament from the nobility and the bourgeoisie, modelled on the Italian statelets (Držić, 1963, pp. 369-387).

In these letters Držić sees the power of Dubrovnik authorities in its ability to impose its own fiction to the world that is to the citizens of the Republic. The more this fiction is unrestrained, a comedian considers, its manifestation is more impressive. Ceremonies, conventions, theatrical rituals are methods of presenting its power.

In that situation Držić tries to deny fiction and to play his own role. He believes that this is absurd: the rulers and the circle around them are crazy, obsessed by gullible fantasies, unable to distinguish between truth and fiction (Greenblatt, 1980, p. 16). He is also aware of his participation in this and his attempts to adapt (akomoduje), to cover up his own nature. It all leads to the disturbing inner emptiness and alienation.

This move is very dangerous. This sense of the human absurdity then at once leads him to social criticism and undermines that criticism, enabling him to ridicule the ideology of the powerful but severely limiting the practical consequences of that ridicule (Greenblatt, 1980, p. 27). However, Držić opts for practical actions, thus avoiding his annulment.After the negative response of the Florentine government, he himself gives up on daring ideas (Kunčević, 2007, pp. 9-46), which has no effect on his attitude, or on its further fate. Physical death of Marin Držić, which is likely but unsubstantiated consequence of his conspiratorial act, had not annulled his escape from alienation, but had just stopped him. Držić remained true to hisattitude perhaps from the reasonhe did not have time to adapt further.

Greenblatt's self-fashioning theory of renaissance literary creators has found its application in the interpretation of the life and work of Marin Držić from Dubrovnik. In this way, the new and more detailed analysis of its specific pastoral, farce and plautancomedy is given, which will prove again the classical quality and timeless value of dramatic works of the renaissance greatest creatorin our region.

\section{CONCLUSION}

Recent studies of Renaissance literature provide us newer access to research of Dubrovnik literature. In this work, it is shown that the methods of new historicism can be applied to the modern perception of the work of Marin Držić. In this way, it has been shown also that the works of his predecessors, contemporaries, and supporters can have their new interpretations when applying Greenblatt's theory of self-fashioning. This primarily refers to the authors whose diverse and rich work provides an opportunity for complex considerations, such as the personality and work of Mavro Vetranović and Nikola Nalješković.

\section{REFERENCES}

Brubaker, R. \& Cooper, F. (2000). Beyond 'Identity'.Theory and Society. 29: 1-47.

Dayre, J. (1930). Marin Držić, conspirateur à Florence. Revue des études slaves. X

Držić, M. (1870). Arkulin. Dubrovnik zabavnik. III

Držić, M. (1963). Izabrana dela. Beograd: Narodna knjiga

Greenblatt, S. (1980). Renaissance Self-Fashioning. Chicago: University of Chicago Press

Kunčević, L. (2007). „Ipak nije na odmet sve čuti“: medičejski pogled na urotničke namjere Marina Držića. Anali Zavoda za povijesne znanosti HAZU u Dubrovniku. XLV: 9-46.

Pantić, M. (1984). "Veliki smijeh" Marina Držića u svomevremenu i danas. Glas SANU, 340, Odeljenje jezika $i$ književnosti. 12: 4-16.

Vetranović, M. (1994). Poezija i drame. Beograd: Prosveta 